\title{
Some Notes on "playing Logos" in Ambiguum 71 of St Maximus the Confessor
}

\author{
Dmitry Kurdybaylo \\ PhD, Research Fellow at Russian Christian Academy for the Humanities; \\ Senior Researcher at Herzen State Pedagogical University of Russia, \\ Saint Petersburg, Russia \\ theoreo@ya.ru
}

\begin{abstract}
In the Ambigua to John 71, Maximus the Confessor discusses a passage of Gregory Nazianzen describing divine Logos that "plays in all kinds of forms." The article emphasises four main approaches of the Ambiguum 71 to 'acquit' the image of 'playful' God. Firstly, St Maximus involves the hyperbolic language of Pseudo-Dionysius to indicate the superiority of divine 'game' over any kind of prudency or playfulness. Secondly, God's playing can be discovered in His providence towards the sensible creations. The third step introduces all the material world as a God's plaything, which can nevertheless be an object of natural contemplation. The fourth approach is merely moral, and its pathetic language conceals tensions between St Maximus' and St Gregory's patterns of thinking. Finally, all four parts are linked in a single structure derived from the triad "practical philosophy - natural contemplation - mystical theology," which was often used by St Maximus.
\end{abstract}

\section{Keywords}

Maximus the Confessor - Ambigua to John - Logos - play - game - aporia 
The last section of the Ambigua to John by Maximus the Confessor discusses a very intriguing passage of Gregory of Nazianzus:

The sublime Word plays in all kinds of forms, judging

His world as He wishes, on this side and on that. ${ }^{1}$

St Maximus' commentary on this passage in the Ambiguum 71 has been discussed several times; and its sources, composition, inner logic, exegetic patterns, and general metaphysical grounds have been analysed. ${ }^{2}$ In the discussion below, I will try to avoid repeating the findings of previous studies as much as possible. Instead, the discussion aims to define what does St Maximus mean, when he uses words "to play" ( $\pi \alpha i \zeta \varepsilon v)$ and "plaything" ( $\pi \alpha i \gamma v i o v)$, and to describe the general structure of the Ambiguum concerning each of its parts.

\section{Lexis and Semantics of "playing" and "plaything"}

The main perplexity in the discussed passage of St Gregory is the description of God who plays. "Playful God" seems to be a kind of an oxymoron, as long as playing games was considered childish since Plato's times, ${ }^{3}$ and almost the

1 Ambigua ad Johannem, 71, PG 91, col. 1408. Quotation of Gregory Nazianzen is from the Ambigua. Here and below English translation (with my minor corrections) and revised Greek text: N. Constas, ed. Maximos the Confessor. On Difficulties in the Church Fathers. The Ambigua. Vols. 1 and 2 (Dumbarton Oaks Medieval Library 28-29), Cambridge, MA, London, 2014. Quoted passage: vol. 2, p. 313 .

2 H. Rahner, Man at Play. New York, 1967, pp. 23-25; C. Steel, "Le jeu du Verbe: À propos de Maxime, Amb. ad Ioh. LXVII," in: Philohistôr: Miscellanea in honorem Caroli Laga septuagenarii, eds. A. Schoors, P. van Deun, Leuven, 1994, pp. 281-293; J.G. Lollar, "To See into the Life of Things" The Contemplation of Nature in Maximus the Confessor's Ambigua to John. (PhD dissertation), Notre Dame, IN, 2011, pp. 26-37; P.M. Blowers, "On the 'Play' of Divine Providence in Gregory Nazianzen and Maximus the Confessor," in: Re-Reading Gregory of Nazianzus: Essays on History, Theology, and Culture, ed. C.A. Beeley, Washington, DC, 2012, pp. 199217; P.M. Blowers, Maximus the Confessor: Jesus Christ and the Transfiguration of the World. Oxford, 2016, pp. 86-9o. A short note on the Ambiguum 71: P. Sherwood, The Earlier Ambigua of Saint Maximus the Confessor and His Refutation of Origenism. Roma, 1955, pp. 70-71.

3 On the pedagogic role of playing games cf.: Plato, Leges $643 \mathrm{~b}_{4}-\mathrm{d}_{4} ; 657 \mathrm{~d} \mathbf{1}-6$, and many other examples. Similar ideas in the writings of Gregory Nazianzen: Or. 42.22, PG 36, col. 484C; Epist. 235.1 (to Adamantius, ed. P. Gallay). More on the sources of this opinion see in quoted works: Rahner, Man at Play; Steel, "Le jeu du Verbe;" Blowers, "On the 'Play' of Divine Providence in Gregory Nazianzen and Maximus the Confessor.". 
only exception of ritual or sacred games ${ }^{4}$ pertained to pagan culture as a rule. Late Antiquity and Middle Ages can be characterised as the time of particular seriousness when even evident episodes of laughter or playing were interpreted with an emphasised prudence. This is especially true for commentaries on the Bible among Christian exegetes, and Plato's dialogues among pagan philosophers, primarily the Neoplatonists. Noteworthy, St Gregory mentions "playthings" ( $\pi \alpha i \gamma \nu \alpha)$ dozens of times in his writings; however, almost all the cases compare a human's life, or the life of the whole humankind, with a play, and particular persons and objects with playthings. Just the discussed passage from the Carmina moralia says about playing Logos. ${ }^{5}$ This rare wording and rare way of thinking about God provoke a reader to search for some explanation.

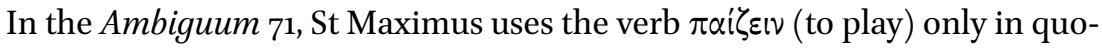
tations from the discussed text of St Gregory, and substitutes it with $\pi \alpha$ irviov (plaything) otherwise. Nicholas Constas has mentioned that this usage reflects St Gregory's use of $\pi$ airviov in the Oratio 7.19. ${ }^{6}$ However, in the whole corpus of St Gregory' writings, $\pi \alpha i \zeta \varepsilon i v$ is used three times more often than $\pi \alpha i \gamma v$ iov. ${ }^{7}$

Firstly, it is necessary to clarify, what are the properties of games, playing and playthings in St Maximus' commentary. The text of the Ambiguum 71 provides the following:

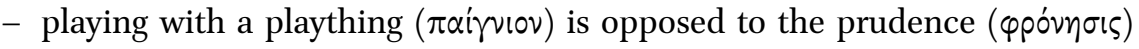
in $71.2(1409 \mathrm{~B})$, and several lines below it is called "privation of prudence"

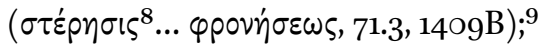

- "plaything of God" ( $\pi \alpha i \gamma v i o v \Theta \varepsilon \circ \hat{v})$ is called the mean term, "which maintains an equal distance from the extremes on account of its fluid ( $\dot{\pi} \pi \dot{\rho} \hat{\rho} \cup \tau \tau v)$ and mutable state of rest ( $\sigma \tau \dot{\alpha} \sigma$ เ $)$, or better, on account of it being a flowing

4 Cf.: J. Huizinga, Homo Ludens: A Study of the Play-Element in Culture. London, 1980, pp. 18-27 et passim.

5 Paul M. Blowers notes that Oratio 14 also mentions human beings as those who "are being played" (Blowers, "On the 'Play' of Divine Providence," pp. 207-208). Nevertheless, in Or. 14, God is not called playful, as the verb $\pi \alpha i \zeta \varepsilon v$ is used in Passive voice, i.e. naming an object of playing but no subject.

6 Constas, Maximos the Confessor. On Difficulties in the Church Fathers. The Ambigua, vol. 2, p. 372 .

7 Carlos Steel reports 28 instances of $\pi \alpha i \gamma v i o v$, and 89 instances of $\pi \alpha i \zeta \omega$ (Steel, "Le jeu du Verbe," p. 282).

8 Here $\sigma \tau \dot{p} p \eta \sigma \varsigma \varsigma$ is used in a common Aristotelian sense, cf.: Categoriae 12a26-13a36 (Bekker).

9 Here and below the Ambigua are quoted with a number of an Ambiguum, followed with a dot-separated section number according to Constas' edition, and comma-separated column number in Migne's PG 91. All references to Ambigua without a following name of its addressee are Ambigua ad Johannem. 


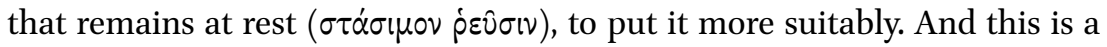
paradox: to behold a state of rest that is forever flowing ( $\sigma \tau \dot{\alpha} \sigma \nu \nu \alpha \dot{\alpha i}$ $\left.\varepsilon^{\prime} \circ v \sigma \alpha \nu\right)$

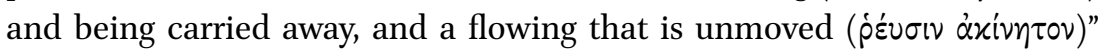
$(71.5,1412 B)$. Below, St Maximus relates this "unmoved flow" with the procession of historical time. However, the imagery of perpetual dynamics, which keeps itself stable in some way, seems to be derived from a more general view on game-playing; ${ }^{10}$

- in the example with parents and their children, adults "taking part in childish games" are depicted as "playing with nuts and knucklebones with them, or showing them many-colored flowers and colorfully dyed clothing to beguile their senses, thereby attracting their attention and filling them with amazement, for young children have no other kind of work or occupation" $(71.7,1413 \mathrm{BC})$. Here, playing is considered the first activity of a child, and a pedagogic means used by adults. At this point St Maximus does not distinguish competitive games from playing with objects;

- a child's plaything ( $\pi \alpha i \gamma v i o v)$ is opposed to "anything true and real" ( $\dot{\alpha} \lambda \eta \theta v \omega$

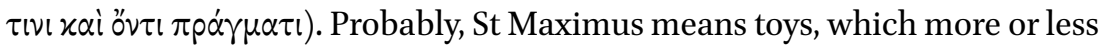
resemble real objects. For instance, a toy horse resembles the real one, but is not alive and does not move on its own;

- in the third contemplation St Maximus again speaks about the instability and flux state of material objects, which "neither maintain their hold over us nor are they held by us" - this condition is also assumed as related to a kind of God's play (71.9, 1416AB);

- finally, a "plaything of God" ( $\pi \alpha i \gamma v i o v . . . \tau \circ \hat{v} \Theta \varepsilon \circ \hat{)}$ ) is a proper name for human beings, who are born, "become children, and ... in the manner of quickly fading flowers, our youth withers into the wrinkles of old age, and dying we are transferred to another life" (71.10, 1416C). The main reason for comparing our earthly life with a toy or a game is their common 'insubstantial' ( $\alpha$ Vov $\mathrm{I}_{-}$

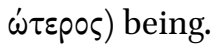

To summarise these points, we can turn to one of the favourite triads of St Maximus: beginning, middle, and end; or, in other terms, a cause, a developing substance, and an aim of its development. If plaything is just a middle term, equidistant from its cause and its aim, or better to say, separated from these extremes, then this is a kind of dynamics that has neither certain reason, nor

10 Noteworthy, in the De creatione hominis, ascribed to Gregory of Nyssa, the opposition of 'flux' and 'stability' is used to explain the creation of man in God's image as stated in

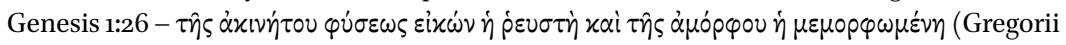
Nysseni opera, suppl., ed. H. Hörner, p. 11). On Heraclitean theory of flux and game see: Rahner, Man at Play, pp. 14-16; Steel, "Le jeu du Verbe." 
any goal. It is just an activity in itself, what seems to be a plausible definition of a game.

Naturally, a playing child does not play because of any reason except his or her will to play. Similarly, playing has no goal other than the joy and amazement of a player. From this standpoint, game-playing is really 'insubstantial' as far as substance is connected with logoi, which determine the start and final stages of object's development. ${ }^{11}$ Therefore, game-playing is not development at all, but just a flow, or flux which never ends. For the same reason, this flow is stable: as far as it has no goal, it does not reach any other condition, i.e. undergoes no substantial change. The lack of substantiality leads to the lack

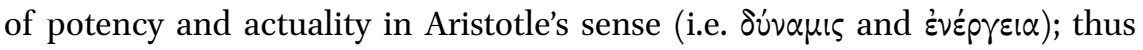

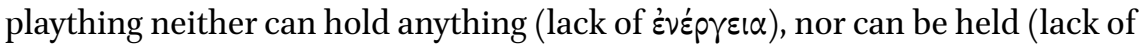

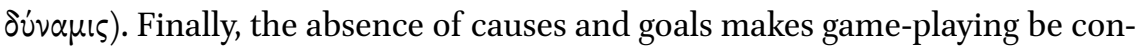
sidered an unserious, childish activity, as opposed to a prudent and thoughtful way of adult life.

This almost negative image of game-playing and playthings builds up the dramatic perplexity of St Gregory's passage on playful Logos. It seems almost impossible or absurd to ascribe an 'unsubstantial' activity to God. Maximus the Confessor provides a series of explanations in four contemplations.

\section{$2 \quad$ Apophatic Language of Play in the First Contemplation}

The first contemplation $(71.2-4,1408 \mathrm{C}-1412 \mathrm{~A})$ is based on the apophatic method of the Areopagite: the terms, which designate privation among people, when applied to God signify "the greatest affirmations" (71.3, 1409B), they

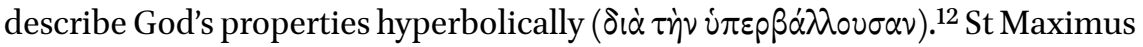
gives an example of 1 Cor. 1:25, where God's 'foolishness' and 'weakness' actually mean His "surpassing wisdom and power," so in the same way 'playfulness' of Logos in St Gregory's verse should point to His "surpassing prudence."

The hyperbolic description of God's properties can be illustrated by the following passage of the De divinis nominibus:

11 There are many works on the conception of particular logoi in the philosophy of St Maximus, for an introduction see, e.g.: J.-C. Larchet, La divinisation de l'homme selon saint Maxime le Confesseur, Paris, 1996, pp. 112-151.

12 This is a very frequent term in the Corpus Areopagiticum, with dozens of instances of $\dot{v} \pi \varepsilon \rho \beta \dot{\alpha} \lambda$ - and $i \pi \varepsilon \rho \beta 0 \lambda$ - in the De divinis nominibus. 


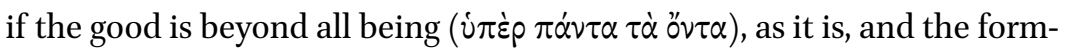

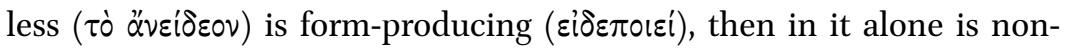

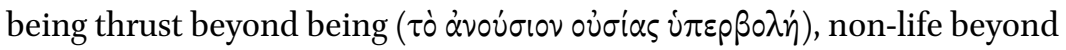

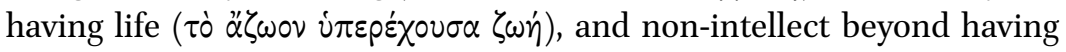
wisdom ( $\tau \dot{0} \alpha \ddot{\alpha}$ ouv $i \pi \varepsilon \rho \alpha i p o v \sigma \alpha \sigma o \varphi i \alpha$ ). Whatever is in the good is of the preeminent form-production of what is formless. Further, if it is lawful so to speak, even non-being ( $\tau \dot{\partial} \mu \grave{\eta}$ óv) itself desires the good beyond all beings, strives somehow to be in the good, and is itself the truly beyond

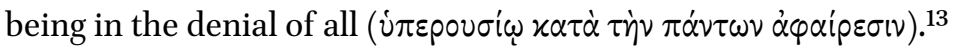

In other words, each God's description in terms of privation actually signify not the absence of the corresponding property but God being its cause, source, and principle. In $D N$ 5.4, the Areopagite says that God surpasses any ontological terms in such a way that it is equally incorrect to call Him either being or not being (Suchla 1990, 182-183). Similarly, we can extrapolate that God is neither living nor not-living, neither wise nor witless, as He is the universal Cause of all life and wisdom. In a similar way, if St Maximus understands games and playthings as the privation of prudence, then when speaking of God, God's play should be the cause of prudence, seriousness and thoughtfulness. However, in the most precise terms, God is neither playful nor prudent.

However, this does not exhaust St Maximus' premise. The context of 1 Cor. 1:25 is closely related to the Incarnation of Logos, which connects the humane properties described as a privation of power, wisdom and prudence with the divine properties, which transcend these three. Therefore, we arrive to a paradox: incarnate Logos does not participate in pure prudence at all: according to His human nature, he is weak and imprudent, and according to the divine one, He surpasses any prudency as its transcendent Cause. Therefore, Logos can be called playful according to both His natures.

The second contemplation of St Maximus $\left(71.5^{-8}, 1412 \mathrm{~B}-1416 \mathrm{~A}\right)$ is related to the abovementioned understanding of a game as a "middle term." Like with the first approach, this one also consists of two parts. The first part depicts

13 DN 4.3; B.R. Suchla, hrsg. Corpus Dionysiacum I: Pseudo-Dionysius Areopagita. De divinis nominibus. Berlin, 1990, p. 146, lines 6-12. English translation: J.D. Jones, tr. Pseudo-Dionysius Areopagite. The Divine Names and The Mystical Theology. Milwaukee, WI, 1999, p. 135 . 
the transcendence of God to the realm of mortals. The game (or plaything) is identified with the temporal, historical being of humans, which is limited by the Creation from one end, and by "the substance of future realities" from the other. These extremes are primary causes and final aims of the mundane being, which are set by God. The sense of transcendence is amplified, when St Maximus engages St Gregory's comparison with "a great chasm in the middle that cannot be crossed, which not only separates the rich man from Lazarus and the longed-for bosoms of Abraham, but also separates the whole of nature that has come into being and is in a state of flux from that which is uncreated and at rest" $(71.6,1413 \mathrm{~A})$. As long as the "middle term" signifies the historical time of the universe, its transcendence to the creation and the eschaton can be understood as a relation between time and eternity. ${ }^{14}$

Then, however, the transcendence of God is overcome by His "condescend"

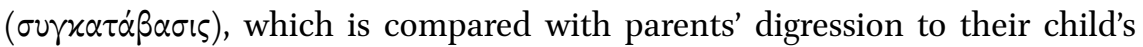
innate inclination to play. Eternal God enters temporal, fluid, unstable, and play-like being of humans due to His providence. Here, St Maximus turns again to the Corpus Areopagiticum:

One must make bold to say even this, on behalf of truth, that the very Author ( $\alpha i \tau 10 \varsigma)$ of all things, through the beauty goodness, and overflow

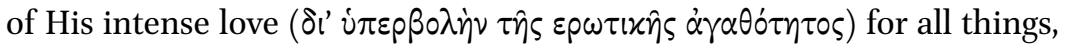

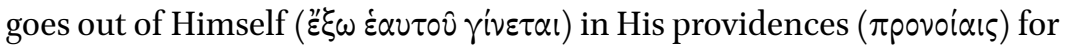
all beings, and is, as it were, spellbound by goodness, love, and longing, and is led down from His position above all and beyond all, to be in all

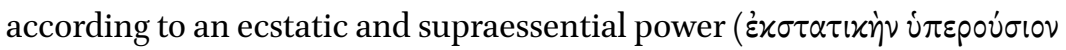

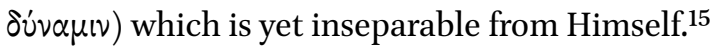

The "ecstatic" "going out of Himself" falls into the meaning of a more general

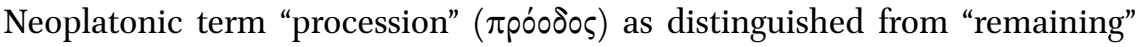

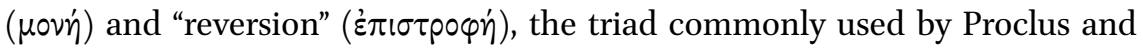
the Areopagite. This parallel is substantial as far as the Areopagite himself never mentions any games or playing, but Proclus does.

In the commentary on Plato's Republic (Essay 6, § 12), Proclus elaborates on Plato's words: "a man ... has been created as a plaything of god ( $\theta \varepsilon \circ \hat{\tau} \tau \iota \pi \alpha i \gamma v i o v$, Leges 8o3c)," adding Homeric imagery of "undying laughter" of Olympic gods: ${ }^{16}$

14 Cf.: Basilius Caesarensis, Hom. in Hexaemeron, 1.5; Gregorius Nazianzenus, Or. 38 (In theophania), 8; PG 36, 320AB.

$15 D N$ 4.13, 159, lines 9-14. Translation by N. Constas of Amb. 71.6.

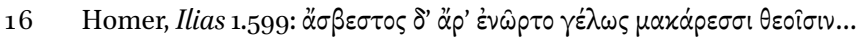


since all providence concerning the sphere accessible to the senses

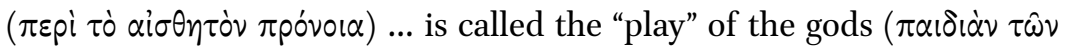
$\theta \varepsilon \hat{\omega} \nu)$ - and for this reason, I believe, Timaeus calls the encosmic gods "young" (vÉous, Tim. 42d6), since they are set over things that are continually coming into being and are properly playthings ( $\pi \alpha \iota \delta \hat{\alpha} \varsigma \hat{\alpha} \dot{\xi} i \omega \nu \pi \rho 0 \varepsilon-$ $\sigma \tau \hat{\omega} \tau \alpha \varsigma \pi \rho \alpha \gamma \mu \dot{\alpha} \tau \omega \nu)$ - the mythoplasts are accustomed to designate the specific quality of this providence of the gods that act within the cosmos as "laughter" ( $\theta \varepsilon \hat{\omega} \nu \gamma \varepsilon \dot{\varepsilon} \lambda \omega \tau \alpha)$.

... [T] he laughter of the gods is to be defined as their generous activity

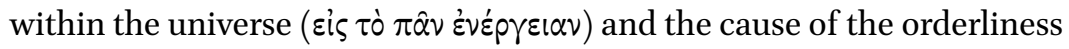

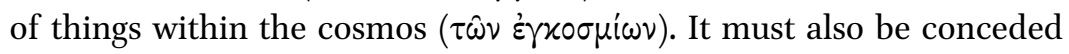
that because such providence is unceasing ${ }^{17}$ and the giving of all good things by the gods is inexhaustible, the Poet chose quite rightly to add that their laughter was "undying $(\alpha \sigma \beta \varepsilon \sigma \tau \circ v)$."18

Proclus expresses similar conceptions in a few other places, providing sufficient evidence to restore his general view on gods' providence as activity towards the material world, and particularly the human race. ${ }^{19}$

There are no significant proofs of possible Proclean influence on Maximus the Confessor. However, the common exegetical pattern of Plato's definition of a man as gods' or God's plaything could have existed even in the times of Gregory Nazianzen, i.e. in the late 4 th century. The most common game-related term of St Gregory is exactly Plato's $\pi \alpha$ irviov, and at least once St Gregory explicitly quotes the Laws 8о3c: $\Theta \varepsilon \circ \hat{v} \pi \alpha i \gamma v i o v$ o $\alpha \nu \theta \rho \omega \pi \circ .^{20}$

Although I could not find any intermediate connections between St Gregory, Proclus, and St Maximus, the likeliness of their approaches makes plausible the assumption of some common conception, which had linked divine providence with playing and a man as a plaything.

One important notice should be added here. Paul Blowers has underlined the link with Plotinus, who elaborated the comparison of human life with a

17 On varia lectio at this place see: R. Lamberton, tr. and ed. Proclus the Successor on Poetics and the Homeric Poems: Essays 5 and 6 of His Commentary on the Republic of Plato. Atlanta, 2012, p. 169, n. 197 .

18 Proclus, in Rem Publicam 1.127.4-27 (Kroll), English translation: Lamberton, Proclus the Successor on Poetics and the Homeric Poems, pp. 167-169. Cf. also another important passage of Proclus discussed in: Steel, "Le jeu du Verbe," pp. 284-291.

19 For examples see: D. Kurdybaylo, "Playing and laughing gods of Plato's dialogues in the commentaries of Proclus," Schole. Ancient Philosophy and the Classical Tradition 15, 1 (2021), pp. 57-6o.

$20 \quad$ PG 38, col. 757 and commentary ad loc. For more datils, see below the discussion of the fourth contemplation in the Amb. 71 . 
stage play (Blowers 2012, 200). Indeed, the Enneads contain a series of passages which expand Plato's phrase from the Laws into a verbose metaphor. ${ }^{21}$ In these passages, Plotinus opposes game playing to being serious, or $\sigma \pi 0 v \delta \alpha^{\alpha}-$ $\zeta \varepsilon \varepsilon v$, that very word, which is also used by Plato in the Leges $803 \mathrm{bc}$. In contrast,

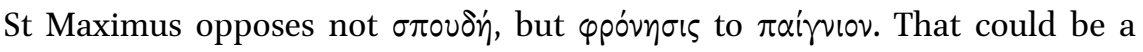
deliberate device aimed to keep a distance from Plato and Plotinus.

Nevertheless, Maximus the Confessor goes beyond the mere conception of God's providence. Actually, in the Ambiguum 71, he just compares the providential "procession" of God into the human realm with that of parents' in their child's activities. But later, in the Quaestiones ad Thalassium, St Maximus further develops this idea. It appears that God "plays up" to the state of the human mind when He appears to our sight within a particular image:

We find that holy Scripture fashions God in terms relative to the underlying disposition of those under His providential care.... When, therefore, God appeared to Abraham - who was perfect in knowledge and who already possessed an intellect completely beyond matter and its figurations - He taught him that the immaterial principle of the Trinity inheres in the principle of its Unity, and for this reason God appeared to him as three and spoke to him as one. When, on the other hand, God appeared to Lot - who had not yet purged his intellect of the composite forms of corporeal things, insofar as he was still conditioned by the generation of corporeal things from matter and form, and still believed that God was the Creator solely of the visible creation - He appeared as a duality and not as a trinity, indicating through the outward form in which He fashioned Himself that Lot's intellect had not yet gone beyond matter and form. Thus, if you examine with true understanding the words in each passage of Scripture when it fashions God in a variety of ways, you will find that the reason for the many variations in the forms of the divine realities is, as we said, the disposition of those who are subject to the activity of providence. ${ }^{22}$

The same explanation is the basis of St Maximus' commentary on Gen. 3:22 "Behold, Adam has become like one of us" in Question to Thalassios 44:

21 Plotinus, Enn. 3.2.15, 3.2.17.

22 Quaest. ad Thalassium 28.2, lines 4-25 in: C. Laga, C. Steel, eds. Maximi confessoris quaestiones ad Thalassium, 2 vols. (CCSG 7, 22), Turnhout, 1980, 199o. English translation: M. Constas, tr. St. Maximos the Confessor. On Difficulties in Sacred Scripture: The Responses to Thalassios. Washington, D.C., 2018, pp. 190-191. 
... Scripture fashions God speaking in terms relative to the underlying disposition of the souls that are under His providence, hinting at the divine counsel through modes that are inherently united to our nature.... For having said: "Behold, Adam has become like one of us," the text adds: "knowing good and evil - and now, lest he put forth his hand and partake of the Tree of Life and live forever," and so on. Inasmuch as the devil had, together with his counsel, taught Adam polytheism, saying: "On the day you shall eat of the tree, your eyes will be opened, and you will be as gods, knowing good and evil," it is with some dissimulation, and, we could say,

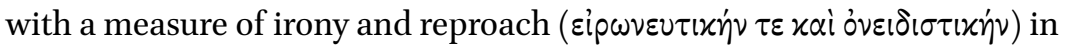
order to censure man who had obeyed the devil, that God uses the plural in the phrase, "he has become like one of us," corresponding to the notion of divinity that the serpent slipped in and used to deceive Adam. ${ }^{23}$

Noteworthy, that this providential 'adaptation' of God to human's disposition

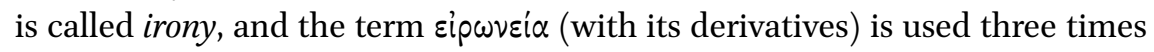
in Question ${ }_{44}{ }^{24}$ followed by other Biblical examples of similar providential God's adaptation.

If the Questions to Thalassios deliver this idea in the most explicit and detailed way, it does not mean that St Maximus did not express it earlier. For example, in the Quaestiones et dubia (QD) this way of thinking is represented twice, in Sections 39 and $120 .{ }^{25}$ The first instance discusses Abraham and Lot almost in the same terms as ad Thalassium 28. In the second passage (QD 12O), St Maximus explains: "since the human being passing through life is quicklychanging being, recklessly shifting with the seasons and events, it is also by definition necessary that divine providence, being one and the same, shifts with our inclinations," and several lines below this 'shift' is identified with "the movement of God's regret," 26 a common wording in the Old Testament.

23 Quaest. Thal. 44.2, lines 7-27; translation: Constas, On Difficulties in Sacred Scripture, pp. 249-250.

24 However, it is not used in any other Question and appears one more time in St Maximus' preface to the Quaestiones (Epist., line 296).

25 See also: Amb. Jo. 10, PG 91, 1193 B. On the divine providence towards each individual person, see: G. Benevich, "God's Logoi and Human Personhood in St Maximus the Confessor," Studi sull' Oriente Cristiano 13, 1 (2009), pp. 137-152.

$26 Q D$ 120, J. H. Declerck, ed. Maximi confessoris quaestiones et dubia. (CCSG 10), Turnhout, 1982; English translation: D. D. Prassas, St. Maximos the Confessor's Questions and Doubts: Translation and Commentary. (PhD Dissertation), Washington, DC, 2003, p. 197. 
A similar conception of infinite God, limiting Himself in order to be perceptible by the intellects with limited nature, is expressed by the Areopagite, who gives it the name of "saving justice."27 Another obvious parallel here is with the imagery of Pedagogue well known since Clement of Alexandria. However, if for Clement incarnate Christ is the divine Pedagogue, St Maximus is speaking about the divine providential pedagogy taken in a much broader sense. ${ }^{28}$

Summarizing these passages, we can see that St Maximus uses various terms to express the mutability of divine providence: it 'shifts,' 'adapts,' expresses 'irony' and 'regret.' The general pattern seems to fit well to the image of parents and a child in the Ambiguum 71, which is also explicitly related to the providence of God. If human life can be called a plaything, then God's providence towards it, which changes, adapts, and ironises, can probably be called God's play - at least metaphorically.

The second contemplation of the Ambiguum 71 bridges the gap between God's transcendence and human imperfection using the terms of mutable providence, while the first contemplation did the same via theology of the Incarnation.

The third contemplation $(71.9,1416 \mathrm{AB})$ is the shortest, and from the first sight just paraphrases the preceding paragraph, i.e. the last paragraph of the second contemplation. What is the difference between them, which seemed so significant for St Maximus that he had to allocate a separate section for it?

The second contemplation's finale opposes "things that are present and visible" to "things that properly and truly exist, ... what in fact are divine and archetypical realities." This opposition is based on the temporal difference, introduced by the distinction of the "mean" term and two extremities: "present" things are compared to those "which will be manifested at a later stage" ( but a plaything ( $\pi \alpha i \gamma v i o v)$, and even something rather less than that." Here the playing is not explicitly related to God, and just recalls the introduction of the second contemplation.

The next section seems to deal with the same opposition; however, it is expressed in a slightly different manner. Here St Maximus speaks of "the

\footnotetext{
$27 \quad$ De divinis nominibus $1.1 ; 109$, line 5 .

28 See also: Steel, “Le jeu du Verbe,” p. 285.
} 


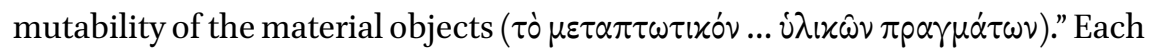

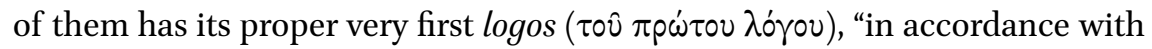
which they are carried along wisely and providentially, and carry us along with them." Nevertheless, it does not prevent them from being instable, mutable, and without a "solid foundation ( $\beta \dot{\alpha} \sigma v)$," so "whereas it might be thought that they can be controlled by us, they slip through our fingers far more frequently than we control them, and they rather almost repel the desire of those among us who insist on clinging to them." The following lines describe the lack of both active and passive efficacy of material things, as it was discussed above.

What obviously distinguishes this discourse from the Amb. 71.8, is the explanation, what is God's game in the context of material instability and flux:

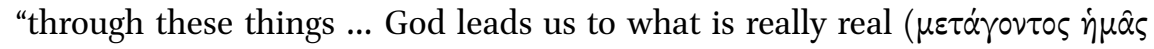

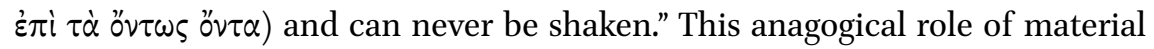
objects, which lead a human intellect to the intelligible realm, is well known under the name of "natural contemplation ( $\varphi v \sigma w \dot{\eta} \theta \varepsilon \omega$ pía)." The basis of this principle is known as long as since Apostle Paul (Rom. 1:20). Since then, it had been developing for Maximus the Confessor being able to distinguish five kinds of natural contemplation. He asserts that one may contemplate "being, motion, difference, mixture, and position" of creatures, and "[t]hrough these, God becomes known to us, insofar as we gather from created beings the implicit traces of God."29 However, what we see in the Ambiguum 71, does not fall into one of the distinguished types. Ambiguum 10.19 gives the following example: "through being, ... we seek the cause of beings and learn from them that such a cause exists," i.e. the anagoge is positive, from sensually perceptible objects and their relations, our mind ascends to the intelligible regularities as their substance, properties, structure, cause, or aim of being. On the contrast, the third contemplation in the $A m b .71$ gives an example of instability and indefiniteness, which stimulate us to search for something substantial, immutable, and intelligible. In other words, this is a kind of contemplation ex contrario, with a certain flavour of apophaticism.

Probably, "God's game" here is not just natural contemplation in general, but precisely the natural contemplation through the opposites, ${ }^{30}$ leading from mutable 'playthings' to substantial things, which are "really real." Noticeably,

29 Amb. Jo. 10.19, 35; 1133AB; translation: Constas, On Difficulties in the Church Fathers, vol. 1, pp. 203-205.

30 Opposition of this kind is close to Areopagitic conception of 'dissimilarity' in the De caelesti hierarchia 2, where the incongruity of biblical God's and angels' imagery is said to be leading a reader to reject any explicit analogies and to search for the invisible and 'dissimilar' truth. 
this 'game' to be called the activity of God implies that human intellect does not ascend by its own, but is being elevated by the power of God. ${ }^{31}$

\section{$5 \quad$ Ethical perspective of the fourth contemplation}

The fourth and final contemplation (71.10, 1416CD) sounds the most pathetic:

we ourselves ... are now born like the rest of the living creatures on the earth, after which we become children, and after which, in the manner of quickly fading flowers, our youth withers into the wrinkles of old age, and dying we are transferred to another life - then not without reason are we

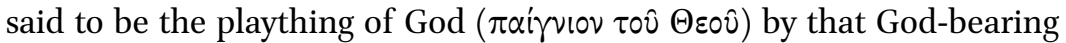

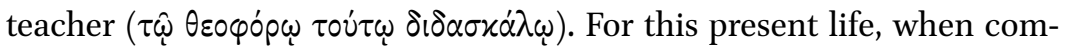
pared to the archetype of the divine and true life that is to come, is a child's toy ( $\pi \alpha$ irviov), than which no other such toy could be more insub-

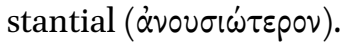

The teacher states this much more clearly in the funeral oration for his brother Kaisarios, when he says: "Such is our life, brothers, of we who live only briefly: a sort of game played upon the earth ( $\tau \dot{0} \dot{\varepsilon} \pi \hat{\imath} \gamma \hat{\eta} \varsigma \pi \alpha i \gamma v i o v)$. Not having existed, we were brought into being, and having been brought into being, we are dissolved ..." ${ }^{32}$

Here is the first and the only instance when "plaything of God" is a name for a human person. All the previous instances deal with general terms, such as 'things,' 'objects,' or 'creatures.' When a man is called a "plaything of God," such a wording comes extremely close to abovementioned Plato's passage from

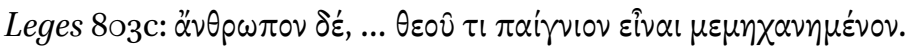

When Maximus the Confessor refers to the "God-bearing teacher," he obviously means St Gregory quoting that very place, which was mentioned

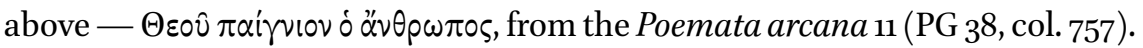
Its Greek text survived only in the commentary of Nicetas David, ${ }^{33}$ who lived in late 9th-1oth centuries, however, it seems to be close to the version quoted by St Maximus.

31 Compare Areopagitic imagery of the "cord suspended from the highest heaven" and the "chains drawing a ship" in the begging of the De divinis nominibus 3 (138.13-139.16).

32 Amb. Jo. 71.10, 1416CD; translation: Constas, On Difficulties in the Church Fathers, vol. 2, pp. $327-329$.

33 For a brief history of Poemata arcana and Nicetas David see: C. Moreschini, ed., D. A. Sykes, tr. St Gregory of Nazianzus. Poemata Arcana. Oxford, 1997, pp. ix, 51-73. 
It is remarkable that St Gregory, who uses term $\pi \alpha$ irviov dozens of times in various contexts, connects it with $\alpha \nu \theta \rho \omega \pi \circ \varsigma$ very rarely: as far as I know, the quoted instance is the only one. The cause of this infrequent usage is almost evident: a Christian writer does not want to be tied to pagan anthropological and theological conceptions, which are implied by this clearly recognizable Plato's quotation. And, of course, the idea of God playing with a human being as a toy is quite unexpected for a Christian theologist. If we look closer at the quoted passage of the Poemata arcana 11, we would see that a man as God's toy is opposed to a person, who believes in Christ. In other words, being a God's plaything is supposed within pagans only, not the whole humankind.

Consequently, it is even more strange, that St Maximus, when quoting St Gregory, applies the state of being a God's plaything to all the people, not excluding the Christians. Also, the following quotation of St Gregory's funeral speech for his brother Kaisarios implies such a universal meaning of a 'plaything,' however, without a reference to God.

Another apparent oddity is seen in the reference to the "God-bearing teacher," who utters words of Plato. As long as the name of St Gregory is not pronounced here, the personality of the 'teacher' is slightly ambiguous. Although the whole discussion is dedicated to the problems of St Gregory's writings, the wording of this very passage leaves a possibility to interpret the "God-bearing teacher" as Plato and not as St Gregory.

St Maximus seems to pay no attention to these difficulties, probably, in view of some assumption, which eliminates their significance. In my view, the primary logical accent of the fourth contemplation is related to the death of a human being. Thus, from the standpoint of death, it is not important in which perspective a human's life is a toy, is it a God's plaything or a plaything of any natural powers. The main premise is that in front of death, all person's earthly concerns are nothing but a game, something transient and insubstantial. For St Maximus, this is merely a moral affair, or, to be more precise, what pertains to the field of "practical philosophy." ${ }^{34}$ This initial stage on the way to ascetic perfection, probably, allows some negligence to the subtle nuances pointed above, which are compensated by less theoretical and more pathetic language.

However, the main question remaining is how the divine 'game' here is an activity of God, not that of a human or of various natural forces of the earthly

34 St Maximus states that "practical philosophy" should lead one's soul to "release ... from the fear and remembrance of the divine judgments," which occur after death (Quaest. ad Thal. 10.2, Constas, On Difficulties in Sacred Scripture, p. 117); similar wording appears in the Epist. ad Thomam 3, lines 90-95 (B. Janssens, ed. Maximi confessoris Ambigua ad Thomam una cum Epistula Secunda ad eundem (CCSG 48), Turnhout, 2002). 
world? Again, from the standpoint of death, this can be explained as the fact that the moment, when God takes a human soul away from the body, is unpredictable and depends on God only. Unfortunately, this is nothing more but our supposition.

\section{$6 \quad$ Four Levels of Understanding the Play of Logos}

Finally, the four contemplations of the Ambiguum 71 seem to be parts of a single composition with well-thought architecture. Moving from the beginning of the Ambiguum to the end, St Maximus starts from the Areopagitic apophaticism and hyperbolic names of God, then continues with the positive theology of divine providence, then with an example of natural contemplation, and finally, comes to the moral extent of practical philosophy. This structure is very close to the common Maximian triad "practical philosophy - natural contemplation - mystical theology,"35 with the only nuance: the first two stages correspond each to single contemplation, while the last stage extents to two contemplations, of which one is primarily apophatic, and the other is primarily cataphatic.

It is quite probable that St Maximus had deliberately chosen such structure and therefore fashioned his four contemplations in a manner to match each of them with the general pattern. There are several facts in favour of this assumption:

- firstly, the third contemplation describes almost the same subject, which is discussed in the last paragraph of the second contemplation. The subtle shift of accents between two consecutive paragraphs could be expressed much more briefly. Moreover, St Maximus could completely evade the third contemplation, or, alternatively, remove the preceding paragraph; ${ }^{36}$

- secondly, there is a noticeable decrease of complexity and verbosity from the beginning to the end, which matches the descending order of stages from mystical theology to practical philosophy;

35 This triad was discussed many times, for example, see: J.-C. Larchet, "Introduction," in: Saint Maxime le Confesseur. Ambigua, tr. E. Ponsoye, comm. D. Staniloae, Paris, 1994, pp. 71-79; L. Thunberg, Microcosm and Mediator. The Theological Anthropology of Maximus the Confessor, 2nd ed. Chicago, 1995, pp. 334-368.

36 Moreover, Polycarp Sherwood considers all three last contemplations having the same ground, and links the fourth contemplation to the third as its 'variation' (Sherwood, The Earlier Ambigua, p. 70). 
- finally, the interpretation of God's play - the primary concern of the whole Ambiguum - has the closest relation to God in the first contemplation, and the weakest one in the finale.

Now, suppose these different levels of contemplation explain the same problematic subject, i.e. it is not the case when each part deals with its own, different 'play of God.' Then, the whole path of St Maximus' discourse shows, that the nature of Logos' play itself is almost lofty, as far as it can be revealed in details at the level of mystical theology. On the contrary, from the standpoint of practical philosophy, it can be expressed merely poetically. Therefore, God's play remains mysterious, complicated and perplexing even from the formal standpoint of the text structure.

\section{Acknowledgement}

The research was supported by Russian Foundation for Basic Research project No 19-011-00749 "Symbol between the ridiculous and the serious in Byzantine exegetics." 